\title{
The effects of glucocorticoid hormone on the expression of c-jun
}

\author{
Heng Lec', Yuch-Tserit Shaw', Shean-Tai Chiou', Wen-Chang Chang', and Ming-Derg Lai't,

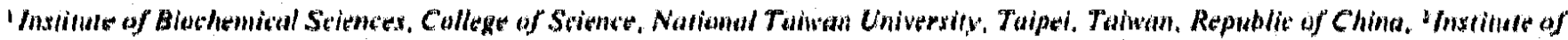

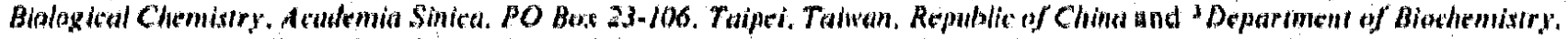 \\ College af Meditine, National Cheng Rung University, Taintm, Taiwam, Republic of China
}

Received 2 Janusiry 1991

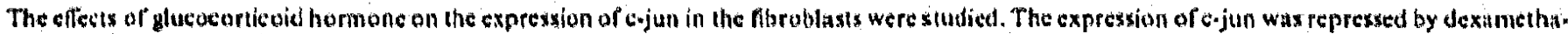

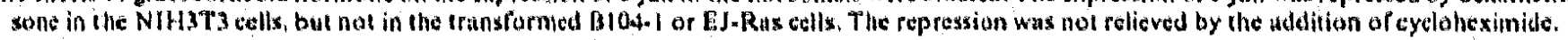

Olucocorticoid: Oncogenc: Jun

\section{INTRODUCTIOH}

The oncogene jun was first identified as the transforming component of avian sarcoma virus 17 which causes fibrosarcomas in chickens [1]. Nucleotide sequence analysis revealed that the C-terminus of $v$-jun shares more than $40 \%$ homology with the C-terminus of yeast transcriptional activator GCN4, which is the DNA binding domain of GCN $[2,3]$. This finding leads to the suggestion that the $v$-jun oncogene product acts as a transcriptional factor to influence the cellular gene expression pattern. Later studies have shown that the human AP-1 (activator protein 1) gene is the cellular homologue of the transforming $v$-jun gene $[4,5]$. The AP-1 complexes consist of several distinct proteins including those encoded by the proto-oncogenes c-jun and $c$-fos, and other members in these two gene families [6-10]. At least two other members, jun-B and jun-D, have been identified in the jun family. Jun-B was shown to inhibit the trans-activating activities of $c$-jun when both were co-transfected into F9 cells [11-14].

Collagenase gene is one of the many genes known to be activated by Jun [15]. The AP-1 site in the promoter of the collagenase gene mediates biological responses induced by phorbol esters, growth factors and steroid hormones [16-21]. Direct interaction between the glucocorticoid hormone receptor and the AP-1 complex on the AP-1 site has recently been demonstrated, and was shown to be responsible for the inhibition of collagenase expression by glucocorticoid hormone in $\mathrm{CV}-1$ cells and other cells [18-21]. As the expression of $\mathrm{c}-\mathrm{jun}$ is regulated by itself, the amount of c-jun mRNA

Correspondence and present address: M.-D. Lai, Department of Biochemistry, College of Medicine, National Cheng Kung University, Tainan, Taiwan, Republic of China should be affected by glucocorticoid hormone according to the model proposed by several groups [18-21]. In this report, we investigated the effects of glucocorticoid hormone on the expression of c.jun in the fibroblasts. The results indicated that the expression of c-jun is indeed inhibited by dexamethasone in NIH3T3 fibroblasts.

\section{MATERIALS AND METHODS}

\subsection{Cell culture}

NIH3T3, B104.1 and EJ.Ras cells were cultured in DMEM sup. plemented with $10 \%$ fetal calf serum in a humidified atmosphere con. taining $5 \% \mathrm{CO}_{2}, 95 \%$ air on $10-\mathrm{cm}$ plastic dishes.

\subsection{RNA isolation and anulysis}

Total RNA was isolated from cells according to the single siep method published by Chomezynski and Sactin [22], and subjecied io agarose gel electrophoresis and Northern blot analysis as described [23]. The plasmid pSV-jun containing cDNA of c-jinn was used to prepare labeled probes for hybridization, pCJ 125 probe containing a tibosomal RNA gene was used as an internal control.

\section{RESULTS AND DISCUSSION}

\subsection{The effects of dexamethasone on the expression of $c-j u n$}

$10^{-6} \mathrm{M}$ dexamethasone was added at time zero to the confluent NIH3T3 cells or B104-1 cells. Cells were harvested at different time intervals and $20 \mu \mathrm{g}$ total RNA was applied each lane. After $12 \mathrm{~h}$, the expression of c-jun decreased significantly in NIH 3 T 3 cells (lane 1 and lane 3, Fig. 1A), and remained low for at least another 24 h (lane 4, Fig. 1A). While the expression of c-jun stayed constant or increased a little in the neutransformed fibroblasts cells, E104-1 cells, as shown in Fig, 1B (the relative level has been determined by densitometry scanning). Similar results were observed in 
A.

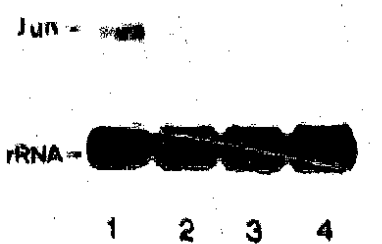

Jun .

RNA -

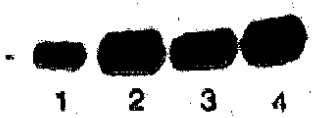

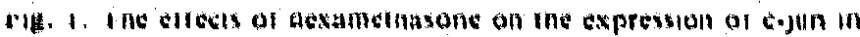
NIHIT3 cells $(A)$ and Bladil edis (b), Celir were harvested al on (lane 1), 4 h (lane 2). 12 h (lane 3), and $36 \mathrm{~h}$ (lane 4) after treatment with dexameihasone. Toinl RNA isolation and Northem blat anslynis were carted oun ax deseribet in section 2.

EJ-Ras cells which are NIH 3 T 3 cells transformed with oncogene ras (data not shown).

\subsection{Cycloheximide cannot relieve the repression caused by dexamethasone}

The effects of glucocorticoid hormone on the expres. sion of several other genes require ongoing protein synthesis. We wished to study the role of de novo protein synthesis during the repression of e-jun by dexamethasone. Cycloheximide has been shown to increase the steady-state level of the c-jun mRNA concentration by inhibiting the synthesis of a hypothetic labile protein which can destabilize the c-jun mRNA. A similar ef fect was observed in our experiments (lane 1 and 4, Fig. 2). Comparing the mRNA levels of $c$-jun in the presence of dexamethasone and that in the absence of dexamethasone when cycloheximide was added (lane 3 and 4, Fig. 2), the repression of the expression of c-jun was clearly not affected by the addition of cycloheximide.

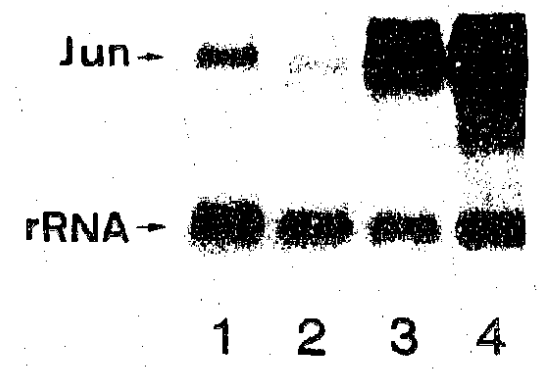

Fig. 2. The ef fect of cycloheximide on the repression of c-jun by dexamethasone. NIH3T3 cells were treaced with dexamethasone or cycloheximide or both for $12 \mathrm{~h}$, and total RNA was isolated, electrophoresesed, blotted and hybridized as described in section 2 . In the cells treated with both dexamethāsone and cycloheximide, cyelohex imide was added $1 \mathrm{~h}$ prior to the addition of dexamethasone. RNA from cells untreated (lane 1), cells treated with dexamethasone (lane 2), cells treated with dexamethasone and cycloheximide (lane 3 ), and cells treated with cycloheximide (tane 4).
In our report, we demonstrated that the expression of e-jun is down-regulated by the glueocorticoid hormene directly in nomal fibroblasis but not in transformed pibroblasis (i.e. B104-1 eclis). The pepression obscrved in NIHIT3 eells is probably mediated through the in. teraction between the glucoeorticold hormone receptor and the AP.I eomplex on the AP. I site in the promoter of ejun [24]. The difference of pexponse to dexamethasone between transformed eells and normal fibroblast eclls possibly reflects the ratio of functional $J$ un and Fos in each cell line aceording to the model proposed by Yamamoto (18). However, other explanations, such as decreasing number of glucocorticoid hor. mone receptor in B 104-1 cells, cannot be exeluded.

Our results and a pecent report by Herrlich et al. [19] indieated that the expression of e-jun can be repressed, induced, or unaffected by the treatment of glucocorticoid hormone in different eell types. Therefore, the interaction between the AP-1 complex and the glucocorticoid hormone receptor on the AP-I site not only affeets the expression of other genes but also affects the expression of e-jun itself.

Acknow/edgements: This work was supported by Grall NSC 79,0203-13002-03 from the Nacional Seience Council in Taiwan, Republic of China. I am grateful to Dr. Inder Verma for the sift of the pSV.jun plasmid and to Dr. Mien.Chie Hung for providing all eell lines used in this study.

\section{REFERENCES}

(1) Maki, Y., Bos, I.J., Davis, C., Starbuck, M. and Vogt, P.K. (1987) Proc. Nall. Acad. Sci, USA 84, 2848-2852.

(2) Vogt, P.K., Bos, T.J. and Doolittle, R.F. (1987) Proc. Nall, Acad, Sci, USA 84, 3716-3719.

(3) Hope, 1.A. and Siruhl, K. (1986) Cell 46, 885-894.

[4] Bohnam, D., Bos, T.J., Admon, A., Nishimura, T., Yogr, P.K. and Tjian, R. (1987) Science 238, 1386-1392.

[5] Angel, P., Allegretlo, E.A., Okino, S.T., Hatrori, K., Boyle, W.J., Hunter, T. and Karin, M. (1988) Nature 332, 166-171.

[6] Sassone-Corsi, P., Lamph, W.W., Kamps, M. and Verma, I.M. (1988) Cell 54, 553-560.

[7) Sassonc-Corsi, P., Ransone, L.J., Lamph, W,W, and Verma, I.M. (1988) Nature 336, 692-695.

[8] Lamph, W.W., Wamsley, P., Sassone-Corsi, P. and Verma, 1.M. (1988) Nature 334, 629-631.

[9] Rauscher, F, III, Sambucetti, L., Curran, T, Distel, R. and Spiegelman, B. (1988) Cell 52, 471-480.

[10] Zerial, M., Toschi, L.. Ryseck, R., Schuermann, M., Muller, R. and Bravo, R. (1989) EMBO J, 8, 805-813.

(11) Nakabeppu, Y., Ryder, K. and Nathans, D. (1988) Cell 55, 907-915.

[12] Halazonetis, T., Georgopoulos, K., Greenbers, M. and Leder, P. (1988) Cell 55, 917-924.

[13] Chiu, R., Angel, P. and Karin, M. (1989) Cell 59, 979-986.

[14] Schutte, J., Viallet, J., Nau, M., Segal, S., Fedorko, J. and Minna, J. (1989) Cell 59, 987-997.

[15] Brenner, D.A., O'hara, M., Angel, P., Chojkier, M. and Karin, M. (1989) Nature 337, 661-663.

[16] Angel, P., lmagawa, $\mathbf{M}_{* ;}$ Chi, $\mathrm{R}_{\text {, }}$ Stein, B., Imbra, R., Rahmsdorf, H., Jonat, C., Herrlich, P. and Karin, M. (1987) Cell 49, 729-739.

[17] Kerr, L.D., Holt, J.T. and Matrisian, L.M. (1988) Science 242, 1422-1427. 
(17) Diamond, M.l. Miner, J.N. Yostinaga, S.K. and Yamamets, K.R. (160ij) Sciente 240, 1360-1272.

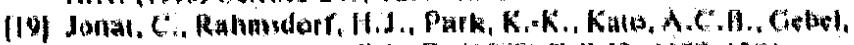

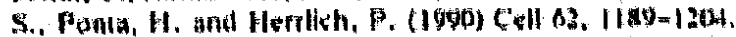

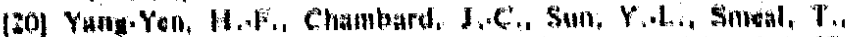
Sihuid, T.J., Drouin, J, and Karin. M. (1940) Call 62 $1205=1215$.

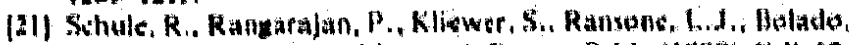
J., Yang. N., Verma, I.M, and Firanr, R.M. (1990) Cell 0., $1217-1226$.

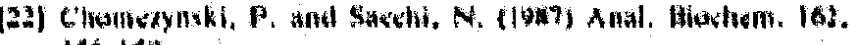
$150=150$.

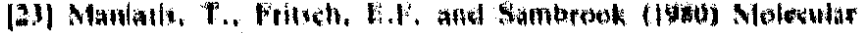
Claning: A Laboratiry Manual, Cula sprine Habor laberalory, Cald Spring Harbor, NY

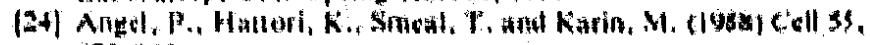
n7s-ings. 